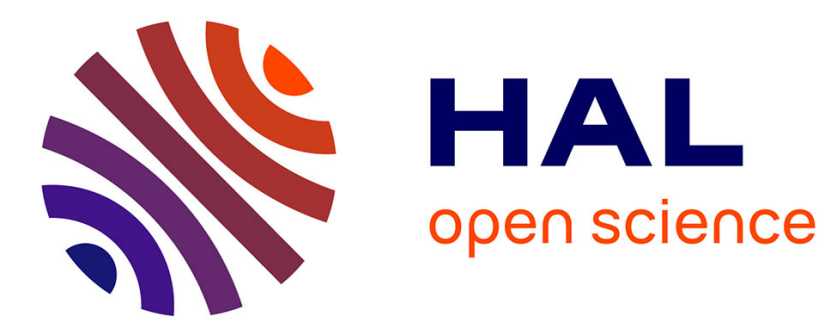

\title{
New pathway for utilization of jarosite, an industrial waste of zinc hydrometallurgy
}

Abd. Maihatchi Ahamed, M.N. N Pons, Q. Ricoux, S. Issa, F. Goettmann, F. Lapicque

\section{- To cite this version:}

Abd. Maihatchi Ahamed, M.N. N Pons, Q. Ricoux, S. Issa, F. Goettmann, et al.. New pathway for utilization of jarosite, an industrial waste of zinc hydrometallurgy. Minerals Engineering, 2021, 170, pp.107030. 10.1016/j.mineng.2021.107030 . hal-03407459

\section{HAL Id: hal-03407459 \\ https://hal.science/hal-03407459}

Submitted on 28 Oct 2021

HAL is a multi-disciplinary open access archive for the deposit and dissemination of scientific research documents, whether they are published or not. The documents may come from teaching and research institutions in France or abroad, or from public or private research centers.
L'archive ouverte pluridisciplinaire HAL, est destinée au dépôt et à la diffusion de documents scientifiques de niveau recherche, publiés ou non, émanant des établissements d'enseignement et de recherche français ou étrangers, des laboratoires publics ou privés. 


\title{
New pathway for utilization of jarosite, an industrial waste of zinc hydrometallurgy
}

Abd. Maihatchi Ahamed ${ }^{1,2}$, M.N. Pons ${ }^{2}$, Q. Ricoux ${ }^{1}$, S. Issa ${ }^{1}$, F. Goettemann ${ }^{1}$, F. Lapicque ${ }^{2 *}$

1 Extracthive, Centre CEA Marcoule, Bât. 51, 30200 Bagnols-sur-Cèze, France

2 Reactions and Chemical Engineering Laboratory, CNRS-University of Lorraine, 1 rue Grandville, 54000 Nancy, France

\begin{abstract}
Generated by zinc hydrometallurgical production and containing several toxic species, jarosite has been little used or beneficiated to date. Utilization of jarosite can save mining resources by producing valuable products, and reduce potential hazards from jarosite disposal. To avoid high energy consumption as in the roasting steps of the current jarosite process, hydrometallurgy has been used in the various steps of an original process aimed at producing valuable zinc-iron alloys from industrial jarosite waste. The process designed consists of three main steps: (i) jarosite leaching by sulfuric acid solutions yielding Fe(III) and $\mathrm{Zn}$ (II) species; (ii) reduction of $\mathrm{Fe}(\mathrm{III})$ to $\mathrm{Fe}$ (II) upon addition of industrial blende; and (iii) electrodeposition of the alloy from the recovered acidic Fe-Zn solution. Care was also taken to limit the amount of alkali to be added by maintaining the $\mathrm{pH}$ in a narrow range; moreover, no specific additives were employed. The various steps of the process have been investigated and the most suitable conditions for high yields have been identified. Among the various impurities in the minerals used and recovered from the acidic solution, copper ions had to be removed by preferential electrodeposition prior to deposition of Zn-Fe alloys. Nevertheless, these results indicated the need for a divided cell to avoid galvanic interference in this last operation from the $\mathrm{Fe}(\mathrm{II}) / \mathrm{Fe}$ (III) couple, which was found to reduce the faradaic yield for alloy deposition from $69 \%$ in the first minutes to $30 \%$ after 30 minutes.
\end{abstract}

\section{Keywords}

Alloy electrodeposition; Beneficiation; Hydrometallurgy; Jarosite; Leaching; Zinc-iron alloys. 


\section{1- Introduction}

Zinc is one of the most heavily used metals in the world. Its production from the mineral concentrate recovered by zinc sulfide flotation (approximately $70 \mathrm{wt} \% \mathrm{ZnS}$ ) consists of three main stages: (i) roasting, (ii) leaching and (iii) electroplating. However, the concentrate usually contains iron in the form of pyrite $\left(\mathrm{FeS}_{2}\right)$, pyrrhotite $(\mathrm{FeS})$ or chalcopyrite $\left(\mathrm{FeCuS}_{2}\right)$ ( $\mathrm{Zhang}$ et al. 2016). During the roasting step, divalent iron combines with zinc species to form zinc ferrite $\left(\mathrm{ZnFe}_{2} \mathrm{O}_{4}\right)$, which is only soluble in hot concentrated acidic media. The solution from the leaching stage contains on average 10 to $30 \mathrm{~g} \mathrm{~L}^{-1} \mathrm{Fe}$ and $70-100 \mathrm{~g} \mathrm{~L}^{-1} \mathrm{Zn}$ (Ropenack et al. 1995). This iron is therefore one of the main impurities in the production of zinc. Four main routes can be used for its elimination: the goethite process (Davey and Scott 1976), the jarosite process (Dutrizac 1999), the hematite process (Coetzee et al. 2017) and the para-goethite method (involving schwertmannite and ferrihydrite), as used by Nyrstar in Australia and Zincor in South Africa. The jarosite process (Dutrizac, Jha et al. 2001) is the most widely used because of its simplicity and moderate cost. This process consists of precipitating iron species contained in the leaching filtrate in the form of jarosite, $\mathrm{XFe}_{3}(\mathrm{OH})_{6}\left(\mathrm{SO}_{4}\right)_{2}$ in which $\mathrm{X}=\mathrm{Na}, \mathrm{K},\left(\mathrm{H}_{3} \mathrm{O}\right)$, $\left(\mathrm{NH}_{4}\right)$, by the addition of sodium, potassium or ammonium sulfate. The precipitation equation can be written as:

$$
\mathrm{X}^{+}+3 \mathrm{Fe}^{3+}+5 \mathrm{SO}_{4}^{2-}+6 \mathrm{H}_{2} \mathrm{O} \rightarrow \mathrm{XFe}_{3}(\mathrm{OH})_{6}\left(\mathrm{SO}_{4}\right)_{2}+3 \mathrm{H}_{2} \mathrm{SO}_{4}
$$

Each ton of zinc produced generates approximately 0.5 tons of jarosite (Štrbac et al. 2011). Because zinc ore also contains other minerals and a slight fraction of zinc is entrapped in solid waste, this solid waste named "jarosite" is polymetallic (Agrawal et al. 2004). In addition to zinc and iron, industrial-generated or mineral jarosites contain arsenic, cadmium and lead, which classify them as hazardous waste (Hallewell et al. 2005). In fact, according to recent studies on the long-term behavior of jarosites, the mineral family can be a source of acidic mine drainage by leaching with natural waters (Sarmiento et al. 2012).

Several studies have been carried out to find ways to make jarosite profitable. In the building construction sector, jarosites can be used in the production of Portland cement by mixing 0.25 to 5\% jarosite with clinker (Asokan et al. 2006, Sharma 2016). Jarosites have also been the subject of several works dealing with extraction of the contained zinc and iron species. The best known works consider a combination of pyrometallurgical and hydrometallurgical operations in the overall process, including (i) reductive firing at approximately $700^{\circ} \mathrm{C}$, (ii) leaching with water or dilute sulfuric acid to extract zinc, and (iii)-magnetic separation (Yang et al. 2014, Zhang et al. 2019). 
In this study, we propose an alternative process for conversion of jarosite waste into value adding products: more precisely, the process investigated here relies on hydrometallurgical operations to produce $\mathrm{Fe}-\mathrm{Zn}$ alloys. Fe-Zn alloys are known to exhibit higher resistance to corrosion than pure zinc for $\mathrm{Zn}$ contents in the range 30-90\% (Jepson et al. 1954). In particular, zinc-iron coatings exhibit high corrosion resistance and excellent mechanical properties (Gomez et al. 1999). While not based on critical or strategic metals, these alloys are used for various applications, such as in the automobile sector. Fe-Zn alloys can be produced from acidic baths (Gomez et al. 1999) as well as in alkaline media (Brenner 2013). The deposition mechanism from mixed zinc and iron salts is described as an anomalous type of codeposition in which zinc is preferentially deposited instead of iron despite the standard potentials of the $\mathrm{Zn} / \mathrm{Zn}^{2+}$ and $\mathrm{Fe} / \mathrm{Fe}^{2+}$ couples (Fukushina et al. 1983, Diaz et al. 2008).

Because of the large tonnage of jarosite generated each year by zinc manufacturers, cheap, robust processes have been considered for each operation, particularly those avoiding the use of additives, specific reagents or catalysts to increase yield and selectivity in this first design. This strategy was also preferred because of the range of jarosite types to be treated. Finally, the hydrometallurgical process was designed to avoid significant $\mathrm{pH}$ adjustment between operations so as to reduce operating costs and to reduce the environmental impact of the process. The considered process consists of the following three steps:

(i) Leaching of jarosite with a sulfuric solution to dissolve trivalent iron and zinc as $\mathrm{Fe}^{3+}$ and $\mathrm{Zn}^{2+}$ ions. For dissolution of pure jarosite at $\mathrm{pHs}$ below 2, for which hydrosulfate ions prevail in sulfuric acid solutions (as shown in a speciation study using PHREEQC mentioned in section 3.1), the reaction can be written as:

$$
\mathrm{XFe}_{3}(\mathrm{OH})_{6}\left(\mathrm{SO}_{4}\right)_{2}+8 \mathrm{H}_{2} \mathrm{SO}_{4}->3 \mathrm{Fe}^{3+}+10 \mathrm{HSO}_{4}^{-}+\mathrm{X}^{+}+6 \mathrm{H}_{2} \mathrm{O}
$$

(ii) The acidic filtrate obtained in step (i) is treated with a given amount of blende (zinc concentrate in the form of $\mathrm{ZnS}$ ) to reduce $\mathrm{Fe}^{3+}$ to $\mathrm{Fe}^{2+}$ with the sulfide, according to the reaction:

$2 \mathrm{Fe}^{3+}+\mathrm{ZnS}->2 \mathrm{Fe}^{2+}+\mathrm{Zn}^{2+}+\mathrm{S}($ solid $)$

This step has two advantages: first, it allows $\mathrm{Zn}$ enrichment of the electrolytic bath; second, only two electrons are required for the reduction of Fe species to Fe metal in the electroplating step below.

(iii) The liquor from step (ii) is used for the electroplating of Fe- $\mathrm{Zn}$ alloys. Because steps (i) and (ii) are carried out under acidic conditions, the alloys are produced at an 
acidic $\mathrm{pH}$. Investigations of this step principally have been aimed at determining the potential and bottlenecks in Fe-Zn alloy production, and this has to be considered preliminary work only.

The jarosite samples to be used in the process consist of $\mathrm{XFe}_{3}(\mathrm{OH})_{6}\left(\mathrm{SO}_{4}\right)_{2}$ in the presence of other metals or elements. Moreover, for the sake of reduced operating costs in step (ii), raw blende minerals can be used instead of pure zinc sulphide. As a result, the electrolytic liquor obtained contains metal ions other than zinc and iron: its direct use for $\mathrm{Zn}-\mathrm{Fe}$ alloys cannot be considered without pretreatment for removal of the main metal impurities, which could affect the properties of the alloys to be produced. Therefore, the fractions of jarosite and blende used here have been thoroughly analyzed and characterised to identify the nature and contents of the metal impurities expected in the resulting liquor, making it possible to choose the most suitable pretreatment technique prior to Fe/Zn electrodeposition. Thereafter, the two leaching steps were carefully investigated on a bench scale to find the optimal conditions minimizing the amount of reagents required. The electrochemistry of $\mathrm{Zn}-\mathrm{Fe}$ alloy deposition has been investigated for decades: our purpose has been restricted to assessing the operational feasibility of using the liquor recovered after pretreatment in a simple, undivided cell and recommending the most suitable conditions for the preparation of $\mathrm{Fe} / \mathrm{Zn}$ alloys.

\section{2- Experimental section}

\subsection{Chemicals used}

Industrial samples of jarosite and blende were provided by Nordenhammer Zinkhütte (Germany) of the Glencore group. The jarosite was taken directly from the process at the end of the iron precipitation step. The blende was a zinc sulfide concentrate formed by ore flotation, and its zinc sulfide content was specified at $81 \%$ by the supplier.

All chemical reagents used here were VWR (Strasbourg, France) products. Sulfuric acid solutions with different concentrations were prepared from technical grade $96 \%$ sulfuric acid and deionised water. Sodium hydroxide solution $(2 \mathrm{M})$ was prepared from $50 \mathrm{wt} \% \mathrm{NaOH}$ concentrated liquors. Hydrochloric acid (1 M) solutions were prepared from analytical grade $(37.5 \%) \mathrm{HCl}$.

\subsection{Characterization techniques}


The solids obtained from the supplier or produced in the steps of the process were characterized in terms of particle size distribution, morphology, chemical composition and mineralogical phases. Particle size distributions were determined by using a Mastersizer 2000 (Malvern) instrument: prior to measurements, the solid suspensions were submitted to ultrasonication for 10 minutes to induce deagglomeration of large solid entities. Solid particles were observed by scanning electron microscopy (Jeol JSM T330A). Mineralogical characterization was performed by X-ray diffraction using a Bruker diffractometer (D8 Advance), and the signals were interpreted using $\mathrm{Eva}^{\mathrm{TM}}$ software. The various solids used or formed were subjected to digestion by aqua regia or by alkaline fusion: the solutions obtained were analyzed by atomic emission spectroscopy with inductively coupled plasma (ICP-AES). After electrodeposition tests, deposits were dissolved in $1 \mathrm{M}$ nitric acid before ICP-AES analysis of the recovered solution. All other solutions were also analyzed by this technique.

It must be kept in mind that, depending on the fractions sampled from the solid stocks, their chemical composition and the solutions produced could change slightly in replicate experiments, taking into account the existence of various steps in the overall process from jarosite leaching to electrodeposition tests. The relative deviation in the various metal contents was usually on the order of $5 \%$. The data given here are values averaged over the various tests performed.

\subsection{Reacting devices}

Leaching of jarosite was conducted in a Pyrex ${ }^{\circledR}$ double-walled reactor with a volume of either $1 \mathrm{~L}$ or $2.5 \mathrm{~L}$. Circulation of thermostated water or oil allowed control of the temperature. Either $800 \mathrm{~mL}$ or $2 \mathrm{~L}$ of sulfuric solution was introduced in the vessel, and a fixed amount of solid was introduced after stabilization of the temperature: jarosite particles were kept suspended by rotation of a $50 \mathrm{~mm}$ long $8 \mathrm{~mm}$-diameter magnet at $400 \mathrm{rpm}$. Tests were carried out by varying the solid charge introduced from 100 to $300 \mathrm{~g}$ per liter of acidic solution, the temperature from 20 to $80^{\circ} \mathrm{C}$, and the sulfuric acid concentration of the leaching solution from 1.5 to $4 \mathrm{M}$. Three solid/liquid ratios $\left(100,200\right.$ and $\left.300 \mathrm{~g} \mathrm{~L}^{-1}\right)$ were used to optimize the experimental leaching conditions. A lid was placed on the cell to avoid excessive evaporation. Samples $(2 \mathrm{~mL})$ were taken after 15, 30, 180 and 420 minutes in seven-hour long analytical runs. Solution pH was measured at the end of the runs. A stock of leachate solution was prepared by leaching jarosite at $300 \mathrm{~g} \mathrm{~L}^{-1}$ for 7 hours and at $80^{\circ} \mathrm{C}$, with the initial concentration of sulfuric acid at $1.5 \mathrm{M}$. 
Fe(III) species were reduced by blending (step (ii)) in the 1 L reactor, with comparable techniques and protocols, in runs lasting up to 7 hours. However, the progress of the redox reaction was monitored using an indicator electrode immersed continuously in the reacting slurry: the combined electrode (VWR RD 113) was provided with a $\mathrm{Ag}-\mathrm{AgCl}$ reference and was connected to a multimeter to monitor the potential. Because the redox reaction studied here was for the $\mathrm{Fe}(\mathrm{II}) / \mathrm{Fe}(\mathrm{III})$ couple, the voltage recorded could be compared to the standard value of this couple at $0.771 \mathrm{~V}$ vs. NHE, i.e., $0.566 \mathrm{~V}$ vs. $\mathrm{Ag}-\mathrm{AgCl}$ at $25^{\circ} \mathrm{C}$. The presence of other metal ions likely resulted in variations in the potential, which were thus taken as indicative only. The progress of the redox process was more accurately monitored by the increase in $\mathrm{Zn}^{2+}$ concentration in the solution, with an uncertainty estimated at 5\%. The above stock solution was submitted to blende dissolution, and the filtrate recovered was submitted to $\mathrm{pH}$ adjustment with $12.5 \mathrm{~mol} \mathrm{~L}^{-1} \mathrm{NaOH}$ to establish a $2-2.3 \mathrm{pH}$ range, as will be explained later.

The electrochemical cell used in step (iii) was formed with a $150 \mathrm{~mL}$ glass beaker. The cathode was either impregnated graphite or a nickel rod $10 \mathrm{~mm}$ in diameter and with an active area of $19.4 \mathrm{~cm}^{2}$. The counter electrode was a grid of platinized titanium (Ampere Industries) with an overall area of approximately $56 \mathrm{~cm}^{2}$, and it was folded in a cylindrical form surrounding the cathode. A Ag- $\mathrm{AgCl}$ reference electrode was continuously immersed in a $100 \mathrm{~mL}$ solution stirred with a $25 \mathrm{~mm}$ long magnet. Electrochemical measurements were carried out using a BioLogic potentiostat SP150 connected to a 10 A Bio-Logic booster. All electrodeposition tests were carried out by chronopotentiometry (at fixed current) preceded each time by cyclic voltammetry at 20 or $50 \mathrm{mV} / \mathrm{s}$ ). For the deposition tests, the solution was stirred at $400 \mathrm{rpm}$ using a magnet. At the end of the test, the cathode was removed from the bath, washed, dried and weighed to estimate the deposited amount. The deposit was stored under vacuum to hinder oxidation upon contact with air.

\section{3- Results and discussion}

\subsection{Characterization of the solids and process definition}

\section{$\underline{\text { Jarosite }}$}

The jarosite used was a polydisperse powder consisting of fine particles measuring approximately $10 \mu \mathrm{m}$ and middle-sized particles measuring approximately $120 \mu \mathrm{m}$, although a significant fraction was formed as solid $0.5-1 \mathrm{~mm}$ agglomerates that could not be deagglomerated by prior ultrasound treatment. ICP-AES analysis of the jarosite digestate revealed the presence of $\mathrm{Fe}$ and $\mathrm{Zn}$ species together with other metals, e.g., $\mathrm{Pb}, \mathrm{Cu}, \mathrm{Al}, \mathrm{Ca}$ and 
$\mathrm{K}$. The weight fractions of the metals present in the jarosite fraction at appreciable levels are reported in Table 1. Ti, Cd, Mn and As were also found at levels below $0.1 \mathrm{wt} \%$.

The main mineral phases in the jarosite were clearly shown by XRD (Figure 1a), which indicated the presence of lead sulfate, zinc sulfate, zinc ferrite and $\mathrm{K}$-jarosite $\mathrm{KFe}_{3}(\mathrm{OH})_{6}\left(\mathrm{SO}_{4}\right)_{2}$. The presence of this last mineral is consistent with the appreciable $\mathrm{K}$ content in the jarosite fraction studied. Quantitative determination of the relative importance of the four minerals could not be carried out with sufficient accuracy. Assignment of the various metals to mineral forms was attempted by assuming, for instance, that copper, calcium, aluminum and lead were present exclusively in the form of sulfates. However, Figure 1a shows that iron is present in both K-jarosite and zinc ferrite with comparable significance. Zinc exists in ferrite as well as in zinc sulfate.

Simulation of the speciation and solubility estimates of the various minerals present was achieved by using PHREEQC thermodynamic software (Parkhurst and Appelo 2013). Kjarosite $\mathrm{XFe}_{3}(\mathrm{OH})_{6}\left(\mathrm{SO}_{4}\right)_{2}$ is soluble in aqueous media at $\mathrm{pH}$ values below 0.5 , according to eq. (2), and it precipitates in less acidic solutions. Lead sulfate can be considered insoluble in acidic media, whereas the other sulfates are soluble salts. The solubility of zinc ferrite could not be predicted by thermodynamic simulations. However, its dissolution in acidic media is described in eq. (4):

$$
\mathrm{ZnFe}_{2} \mathrm{O}_{4}+8 \mathrm{H}_{2} \mathrm{SO}_{4} \rightarrow \mathrm{Zn}^{2+}+2 \mathrm{Fe}^{3+}+8 \mathrm{HSO}_{4}^{-}+4 \mathrm{H}_{2} \mathrm{O} \text { for } \mathrm{pH}<2
$$

The process has been shown to be controlled by surface reactions of protons, with a rate constant proportional to the square root of proton activity and an activation energy near $72 \mathrm{~kJ} \mathrm{~mol}^{-1}$ (Elgersma et al. 1992). Dissolution via the process of step (i) cannot be fully excluded, particularly at $80^{\circ} \mathrm{C}$. It must be kept in mind that the two leaching reactions (2) and (4) are acidbase reactions that consume acid.

\section{$\underline{\text { Blende }}$}

The blende was a powder formed of particles whose size distribution exhibited a single, broad peak in the range 10 to $150 \mu \mathrm{m}$. Analysis of the solid revealed the predominance of zinc and sulfur with appreciable levels of $\mathrm{Fe}, \mathrm{Pb}, \mathrm{Na}$ and $\mathrm{Ca}$ (Table 2). Copper, although detected, could not be quantified with sufficient accuracy.

XRD spectra of the blende (Fig. 1b) show large peaks related to zinc sulfide (ZnS) and smaller peaks due to the presence of chalcopyrite $\left(\mathrm{CuFeS}_{2}\right)$, pyrite $(\mathrm{FeS})$, galena $(\mathrm{PbS})$ and anglesite $\left(\mathrm{PbSO}_{4}\right)$. Dissolution of anglesite appears unlikely in the expected acidic liquor. Dissolutions 
of pyrite and chalcopyrite are very limited in acidic media, but for blende, the two sulfides can be oxidized chemically, e.g., by trivalent iron or dissolved oxygen (Demoisson et al. 2007), or electrochemically at potentials greater than $950 \mathrm{mV} / \mathrm{NHE}$ (Antonijevic and Bogdanovic 2004). However, as with jarosite, the exact amounts of pyrite and chalcopyrite could not be determined by XRD.

\section{Copper removal and the electrochemical process}

From the analysis of the two industrial solids to be used, it appears that copper ions should be present in the solution generated by step (ii), but the other impurities present at sufficiently low levels can be discarded in the electrochemical step. Although the concentration of $\mathrm{Cu}$ (II) species can be expected to be at least one order of magnitude lower than those of divalent $\mathrm{Fe}$ and $\mathrm{Zn}$, direct use of the above solution for electrolytic production of alloys would result in $\mathrm{Cu}-$ containing Fe-Zn alloys. The resistance-to-corrosion capacity of these alloys could be affected by the presence of copper (Winand 2011). Therefore, removal of copper cations from the liquor had to be carried out between steps (ii) and (iii).

Copper ion removal was carried out by preferential electrodeposition. Electrodeposition of the three metals can compete with hydrogen evolution, for which the reversible potential is reduced by $59 \mathrm{mV}$ per $\mathrm{pH}$ unit. However, $\mathrm{pH}$ values that are too low can result in precipitation of metal hydroxides, particularly near the cathode surface. It was therefore desirable to consider partial neutralization of the solution up to $\mathrm{pH}=2$, as indicated in the process flowsheet (Figure 2), so that successive depositions of copper and zinc-iron alloys could then be achieved with limited hydrogen evolution.

\subsection{Leaching of jarosite}

To estimate the amount of acid required for a given amount of jarosite, assumptions on the presence - or absence - of some minerals had to be made. Hence, if one neglects here the presence of zinc ferrite in the jarosite sample - in spite of XRD evidence for its existence - the significance of the main minerals revealed by XRD could be approximated from the chemical composition (Table 1) by taking into account the molecular weights of the various elements involved. The results are presented in Table 3. Estimation of the solid composition in terms of mineral fractions allows a better understanding of the mechanism for jarosite dissolution (Fan et al. 2019), despite possible zinc ferrite dissolution at $80^{\circ} \mathrm{C}$, which was not examined here. 
Tests were carried out by varying the solid charge introduced to the acidic solution from 100 to $300 \mathrm{~g} \mathrm{~L}^{-1}$, the temperature from 20 to $80^{\circ} \mathrm{C}$, and the sulfuric acid concentration of the leaching solution from 1.5 to $4 \mathrm{M}$. At the end of the leaching tests ( 7 hours), the solution $\mathrm{pH}$ was in all cases lower than 1, which confirms the leaching stoichiometry (Eq. 2). To interpret the data, zinc ferrite was assumed to be absent from the mineral solid treated in this subsection.

To investigate the effect of the solid charge introduced, the concentration of sulfuric acid was kept at $1.5 \mathrm{M}$ and the temperature at $80^{\circ} \mathrm{C}$. These conditions should be sufficient to dissolve the zinc ferrite in addition to the jarosite. Assuming no zinc ferrite is present in the jarosite fraction, the stoichiometry of Eq. 2 could lead to an excess or deficiency of acid introduced for the test, depending on the solid charge introduced. For $100 \mathrm{~g} \mathrm{~L}^{-1}$, the amount of excess sulfuric acid was close to $39 \%$, whereas for tests carried out at 200 and $300 \mathrm{~g} \mathrm{~L}^{-1}$ the amount of acid introduced was not sufficient for complete leaching, since the solutions contained approximately $70 \%$ and $46 \%$ of the acid required for the leaching process shown in Eq. 2. The leaching efficiency with respect to zinc and iron is given in Figure 3; both variations are increasing functions of time, with high and increasing rates in the first minutes, then gradually slower progress in the dissolution.

Trivalent iron species are formed in the leachate only by the dissolution of K-jarosite. Fe was found to be leached at levels of 75, 62 and 39\% for solid charges of 100, 200 and $300 \mathrm{~g} \mathrm{~L}^{-1}$, respectively (Figure 3a). For the case of the two most concentrated suspensions, the final leaching efficiency was comparable to the amounts of acid introduced as a percentage of the amount required for full leaching of the initial K-jarosite; these were approximately $70 \%$ and $46 \%$, as explained above. Leaching for longer periods did not significantly enhance the extent of leaching (data not shown). Zinc dissolution was observed to be very fast in the first 15 minutes (Fig. 3b), faster than that of iron. It was assumed that zinc is only present in zinc sulfate, for which dissolution does not involve acid consumption, so the kinetics may be expected to be fast. Moreover, the final fraction of zinc leached constituted only $70 \%$ of the total with a $100 \mathrm{~g}$ $\mathrm{L}^{-1}$ charge and $52 \%$ of the total for the two most concentrated suspensions. These two results reveal that zinc sulfate was presumably not the only $\mathrm{Zn}$-containing mineral and that zinc ferrite was actually present and was leached over time. For the $100 \mathrm{~g} \mathrm{~L}^{-1}$ suspension, the excess acid seemed to allow sustained leaching of the ferrite in the last hours, whereas the dissolution stopped in the two other media because of insufficient proton activity. Dissolution of copper followed kinetics comparable to those for zinc (data not shown), and the final leaching efficiency varied from $55 \%$ to $76 \%$ depending on the solid charge introduced. As described for 
zinc, copper sulfate was probably not the only $\mathrm{Cu}$-containing phase in the jarosite sample. The contents of the solutions after 7 hours are reported in Table 4 and depend on the solid charge introduced. Although incomplete, the leaching of concentrated suspensions of the mineral jarosite allows generation of fairly high concentrations of iron and zinc.

Two solid charges were considered for investigating the effect of temperature: $100 \mathrm{~g} \mathrm{~L}^{-1}$ mineral jarosite, i.e., with a theoretical excess of acid, and $300 \mathrm{~g} \mathrm{~L}^{-1}$, for which the quantity of acid introduced was appreciably deficient. The efficiencies of zinc, iron and copper leaching after 7 hours are shown in Figure 4 as a function of temperature. Dissolution of zinc and iron was accelerated at higher temperatures, particularly with an excess of acid (Figure 4a). At $300 \mathrm{~g} \mathrm{~L}^{-}$ 1 , the improvement induced by higher temperatures was less pronounced due to the acid deficiency in the leaching solution (Figure 4b). As discussed above, because dissolution of zinc sulfate can be considered a fast process that is likely controlled by the mass transfer rate, the strong impact of temperature on zinc ion accumulation in the solution was presumably caused by the presence of the more refractory zinc ferrite, for which dissolution requires harsher conditions. Finally, temperature seemed to exert no real effect on copper dissolution, and the final $\mathrm{Cu}^{2+}$ concentration depended only on the excess or deficiency of acid in the initial leaching solution. To conclude the discussion of the temperature effect, since leaching of zinc and iron was more effective at $80^{\circ} \mathrm{C}$, further leaching tests were carried out at this temperature.

The effect of the sulfuric acid concentration was investigated with a $300 \mathrm{~g} \mathrm{~L}^{-1}$ suspension at $80^{\circ} \mathrm{C}$. Increasing the acid concentration in the initial solution modified the deficiency or excess of acid introduced for jarosite dissolution according to Eq. (2). The fraction of species leached$\mathrm{Fe}, \mathrm{Zn}$ and $\mathrm{Cu}$ - is plotted versus the initial sulfuric acid concentration in Figure 5. As expected, a higher leaching efficiency was obtained by using more concentrated solutions, except for with copper, for which the efficiency was approximately $90 \%$ with sulfuric acid concentrations of 2 $\mathrm{M}$ or more. The zinc leaching efficiency was visibly improved by increasing the $\mathrm{H}_{2} \mathrm{SO}_{4}$ concentration from 1.5 to $2 \mathrm{M}$, but a further increase in the acidity resulted in only moderate enhancement, with an efficiency of $69 \%\left(12.1 \mathrm{~g} / \mathrm{L} \mathrm{Zn}^{2+}\right)$ seen with $4 \mathrm{M}$ sulfuric acid. The effect was more significant for iron over the whole range of acid concentrations, and iron was leached at $81 \%$ with the most concentrated solution, corresponding to a final $\mathrm{Fe}^{3+}$ concentration of approximately $54.7 \mathrm{~g} \mathrm{~L}^{-1}$, i.e., almost $1 \mathrm{M}$.

For the sake of comparison, the ratio of the molar amount of acid introduced over that required for full leaching of jarosite as per Eq. 2 was also plotted in Figure 5. Although the two number series were of comparable significance with Fe leaching efficiencies of 1.5 and $2 \mathrm{M}$, their 
deviations from each other became larger with more acidic solutions: at $4 \mathrm{M}$, the acid molar ratio reached 1.24 (24\% excess) but incomplete dissolution of the element still resulted. In practice, it would be preferable to conduct jarosite leaching with 1.5 or $2 \mathrm{M}$ sulfuric acid (for $300 \mathrm{~g} \mathrm{~L}^{-1}$ solid), even though this would result in leaching levels that were far from complete. This would avoid the need for excessively large amounts of alkali in the partial neutralization so electrochemical step (iii) could be conducted with $\mathrm{pH}$ values close to 2 .

\subsection{Reductive leaching of blende}

As expressed above, the solution obtained in step (i) contained $26.6 \mathrm{~g} \mathrm{~L}^{-1} \mathrm{Fe}^{3+}$ species, $9.81 \mathrm{~g}$ $\mathrm{L}^{-1} \mathrm{Zn}^{2+}$ and $0.50 \mathrm{~g} \mathrm{~L}^{-1} \mathrm{Cu}^{2+}$. The $\mathrm{pH}$ measured at ambient temperature was in the range of $0.8-$ 1.0. The addition of blende to reduce $\mathrm{Fe}^{3+}$ to $\mathrm{Fe}^{2+}$ was carried out by varying the temperature from 20 to $80^{\circ} \mathrm{C}$, and the stoichiometric factor $\mathrm{n}$ was defined as the ratio of the moles of pure $\mathrm{ZnS}$ introduced to the moles of $\mathrm{Fe}(\mathrm{III})$ present in the liquid phase.

First, the stoichiometric factor was taken as either 0.42 - corresponding to a deficiency in reducing minerals, or 0.59 , corresponding to an $18 \%$ excess of reductant, based on the stoichiometry of Eq. 3. The temperature was fixed at $50^{\circ} \mathrm{C}$, and the operation was followed for 4 hours. The potential of the working electrode decreased over time (Figure 6a), indicating the progress of reduction of $\mathrm{Fe}^{3+}$ to divalent iron. A larger decrease in the potential was observed with a higher $\mathrm{n}$ value, as expected. Moreover, the rate of the decrease in potential was usually low during the last hour, likely corresponding to a far slower reduction in this period. For the sake of comparison, the standard reference potential of the $\mathrm{Fe}(\mathrm{II}) / \mathrm{Fe}(\mathrm{III})$ couple is also given in

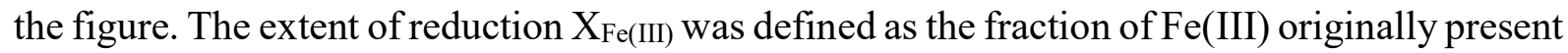
in the liquor that was reduced upon blende addition. This extent was obtained by analysis of the solution after 4 hours. The final zinc concentrations determined led to a reduction extent $\mathrm{X}_{\mathrm{Fe}(\mathrm{III})}$ of approximately $33 \%$ for the test with $n=0.42$ and approximately $49 \%$ for the reduction with excess blende $(n=0.59)$ (Table 5).

The effect of temperature was also studied: the larger decreases in the indicator electrode potential observed at high temperature (Figure 6b) suggested higher reduction extent. This was confirmed by ICP-AES analysis of the final solutions. As shown in Table 5, the reduction was minimally efficient at ambient temperature, but the $\mathrm{Fe}(\mathrm{III})$ conversion was far higher at $80^{\circ} \mathrm{C}$, reaching $83 \%$ at the end of the test. 
Step (ii) can be efficiently carried out with an $18 \%$ excess of blende within a reasonable reaction time (4 hours) at $80^{\circ} \mathrm{C}$. The resulting solution contained $26.6 \mathrm{~g} \mathrm{~L}^{-1}$ iron species (mainly in the form of $\mathrm{Fe}^{2+}$ cations), $22.0 \mathrm{~g} \mathrm{~L}^{-1} \mathrm{Zn}^{2+}$ and $0.50 \mathrm{~g} \mathrm{~L}^{-1} \mathrm{Cu}^{2+}$. The enhanced concentration of zinc species is favorable to the production of Zn-rich alloys.

\subsection{Copper removal from the leaching solution}

To better identify the potential domains for the deposition of the three main metals contained in the solution, cyclic voltammetry was carried out at $40^{\circ} \mathrm{C}$ with a nickel rod. For comparison, tests were also performed with synthetic sulfuric acid solutions of copper and zinc, both with pHs of approximately 2:

- Solution $\mathrm{S} 1$ contained $0.50 \mathrm{~g} \mathrm{~L}^{-1} \mathrm{Cu}^{2+}(0.8 \mathrm{mM})$ upon the addition of copper sulfate and 0.2 M sodium sulfate as supporting electrolyte;

- Solution S2 contained the same concentrations of copper sulfate and sodium sulfate as solution $\mathrm{S} 1$, but the addition of zinc sulfate established a $\mathrm{Zn}^{2+}$ concentration of $22 \mathrm{~g} \mathrm{~L}^{-1}$ $(0.337 \mathrm{M})$ as well.

Voltammograms of the $\mathrm{S} 1 \mathrm{Cu}(\mathrm{II})$ solutions exhibited a reduction wave beginning at $-0.2 \mathrm{~V} / \mathrm{Ag}$ $\mathrm{AgCl}$, with a fairly well-defined plateau from -0.35 to $-0.50 \mathrm{~V} / \mathrm{Ag}-\mathrm{AgCl}$ attributed to copper deposition (Figure 7). The anodic peak near $0.1 \mathrm{~V} / \mathrm{Ag}-\mathrm{AgCl}$ in the reverse scan may correspond to the anodic dissolution of the deposited copper. In the presence of zinc, the voltammograms exhibited a comparable profile but with a less well-defined reduction plateau for $\mathrm{Cu}^{2+}$. The significant rise in current for potentials more negative than $-0.6 \mathrm{~V} / \mathrm{Ag}-\mathrm{AgCl}$ was attributed to a combination of hydrogen evolution and zinc deposition occurring beyond $-0.7 \mathrm{~V}$. Scans performed with the leaching solution were carried out over a broader range of potentials to observe the occurrence of the various electrode reactions. The reduction wave for copper was less visible with the leaching solution. Increasing the negative polarization revealed a slight shoulder on the wave near $-0.8 \mathrm{~V}$, which could be due to Fe deposition; then, for potentials more negative than $-1 \mathrm{~V}$, zinc deposition and hydrogen evolution occurred. The large amount of metal formed in the forward cathodic scan resulted in a far larger anodic peak near $0.25 \mathrm{~V}$ for its reoxidation and dissolution.

Electrodepositions of copper from the three above solutions were carried out at $-0.35 \mathrm{~V} / \mathrm{AgAgCl}$ for quantitative removal of copper. The cell current and the charge passed were monitored, and the cell voltage was measured at regular time intervals. After the 90 minute runs, the solution 
was sampled for $\mathrm{Cu}(\mathrm{II})$ analysis. As shown in Figure 8, the current regularly decreased over time in all cases. For solution S1, application of Faraday's law led to calculation of a current efficiency for copper deposition near $82 \%$, with a final concentration of copper of approximately $83 \mathrm{mg} \mathrm{L}^{-1}$. In the presence of zinc (S2), copper removal was also efficient (93 $\mathrm{mg} \mathrm{L}^{-1}$ after 90 minute electrolysis), but it had a lower current efficiency of $59 \%$. For the leachate, the presence of numerous species was presumably the cause of the significant residual current at the end of the run (with a final $\mathrm{Cu}$ content of $130 \mathrm{mg} \mathrm{L}^{-1}$ ), which was related to the current efficiency of only $48 \%$. Nevertheless, copper removal by preferential deposition should be possible in a scaled up process.

In addition and contrary to what was observed for treatments $\mathrm{S} 1$ and $\mathrm{S} 2$, the cell voltage $\mathrm{U}_{\mathrm{c}}$ with the leaching solution decreased rapidly from its starting value at $1.7 \mathrm{~V}$ and remained in the range 1.35-1.40 V/Ag-AgCl. Taking into account the ohmic drop in the cell (with $\mathrm{R}$ as the ohmic resistance of the cell) and the cathode potential, $E_{c}$, the anode potential was calculated from the cell voltage as follows:

$$
U_{c}=E_{a}-E_{c}+R I
$$

where I is the cell current. Impedance measurements allowed the resistance $\mathrm{R}$ to be estimated as $1.0 \mathrm{Ohm}$. For $\mathrm{E}_{\mathrm{c}}$ fixed at $-0.35 \mathrm{~V}$, the initial anode potential was found to be $1.27 \mathrm{~V} / \mathrm{Ag}$ $\mathrm{AgCl}$, which corresponds to oxygen evolution on the Ti-Pt grid forming the anode. Over time, the anode potential decreased to $1.0 \mathrm{~V} / \mathrm{Ag}-\mathrm{AgCl}$ or below: although this value is slightly larger than the equilibrium potential of the $\mathrm{H}_{2} \mathrm{O} / \mathrm{O}_{2}$ couple at $\mathrm{pH} 2$ (near $0.91 \mathrm{~V} / \mathrm{Ag}-\mathrm{AgCl}$ ), the occurrence of side reactions, e.g., the anodic oxidation of divalent iron, might be considered.

\section{$\underline{3.5 \text { First preparative tests of zinc-iron alloys }}$}

A few tests were carried out with the copper-depleted leaching solution, with a $\mathrm{Cu}$ (II) content of $0.13 \mathrm{~g} \mathrm{~L}^{-1}$. To allow visualization of the alloys, the graphite rod was used as the cathode. The profile of the voltammograms for leaching solutions suggested carrying out deposition at potentials from -1 to $-1.3 \mathrm{~V}$, at which both zinc and iron are expected to deposit. From tests conducted for 30 minutes, the cell current (abs. value) was in the range 200-800 mA, corresponding to a current density lower than $400 \mathrm{~A} / \mathrm{m}^{2}$, a typical order of magnitude for zinc or zinc alloy deposition in acidic media (Brenner, Gomez et al). Electrodeposition tests were carried out at $40^{\circ} \mathrm{C}$ with a freshly $\mathrm{Cu}$-depleted leaching solution and the absolute current density varied from 100 to $200 \mathrm{~A} / \mathrm{m}^{2}$, which corresponded to cathode potentials between $-1 \mathrm{~V}$ and -1.3 
$\mathrm{V} / \mathrm{Ag}-\mathrm{AgCl}$ (Figure 7). Both the cathode potential and the cell voltage were monitored, so the time variation of the anode potential could be deduced using eq. (5). Whereas the anode potential was observed to remain fairly constant in the 15 min test, the cathode potential increased by more than $400 \mathrm{mV}$ at $-140 \mathrm{~A} / \mathrm{m}^{2}$, as shown in Figure 9. The final cathode potential measured at $-0.82 \mathrm{~V} / \mathrm{Ag} / \mathrm{AgCl}$, i.e., $0.615 \mathrm{~V} / \mathrm{NHE}$, indicated the occurrence of reactions other than zinc or iron deposition. In addition to the visible hydrogen evolution, $\mathrm{Fe}^{3+}$ species either present in the introduced solution or generated at the anode by $\mathrm{Fe}^{2+}$ oxidation were reduced to $\mathrm{Fe}^{2+}$ at the cathode. The presence of the galvanic couple $\mathrm{Fe}(\mathrm{II}) / \mathrm{Fe}(\mathrm{III})$ in the cell actually resulted in far lower selectivity for the desired reactions, namely, oxygen evolution at the anode and $\mathrm{Fe}-\mathrm{Zn}$ deposition at the cathode.

In the first minutes, a compact gray deposit appeared on the graphite surface, but the deposit later turned dark brown. Analysis of the deposit recovered after 30 minutes revealed the presence of zinc and iron, but with a faradaic yield lower than $30 \%$. The tests were repeated with fresh solutions and with deposition times limited to 5 minutes to avoid an overly significant level of cathode side reactions. Analysis of the thin deposit by ICP-AES after its dissolution gave access to the faradaic yield as a function of the current applied. Only copper, zinc and iron could be quantified in the small amounts of deposit recovered, so the weight fractions reported in Table 6 were adjusted so that their sums equated $100 \%$. These data demonstrate the feasibility of the deposition, at least for brief periods, with acceptable faradaic yields, particularly at high current density. The copper content, although moderate, could be largely reduced by longer pretreatment of the solution at $-0.35 \mathrm{~V}$.

Improvement of the electrochemical step leading to quantitative production of $\mathrm{Zn}$-Fe could be obtained only by the use of a divided cell to avoid oxidation of $\mathrm{Fe}$ (II) at the anode and development of the $\mathrm{Fe}(\mathrm{II}) / \mathrm{Fe}(\mathrm{III})$ galvanic couple. Few authors have considered such cells for $\mathrm{Zn} / \mathrm{Fe}$ alloy deposition (Fukushima et al.) since the presence of a membrane or a separator is often avoided for the sake of simplicity.

\section{4- Conclusion}

A novel process for the utilization of the mineral jarosite has been designed for the production of $\mathrm{Zn}-\mathrm{Fe}$ alloys. Because of the moderate value of the industrial mineral waste, the process must be simple and robust and exhibit limited emissions, and it cannot rely on the addition of large amounts of acids, bases or chemical agents used to improve the yield. The jarosite to be treated is first leached in moderately concentrated sulfuric acid at high temperature to produce $\mathrm{Zn}$ - and 
Fe(III)-rich acidic solutions. Blende is then added to the recovered liquid to reduce trivalent iron species to divalent iron and increase the $\mathrm{Zn}^{2+}$ concentration. The slight amounts of copper salts present in the liquid and originating from the jarosite can be removed efficiently by preferential electrodeposition with control of the cathode potential in a domain less cathodic than the equilibrium potentials of the $\mathrm{Zn} / \mathrm{Zn}^{2+}$ and $\mathrm{Fe} / \mathrm{Fe}^{2+}$ systems.

In view to evaluating its industrial viability, the process designed here could be further improved, as explained below:

- The process could first be simplified by coupling the first two steps, actually carried out under the same $\mathrm{pH}$ conditions and at the same temperature, by simultaneous dissolution of jarosite and blende in sulfuric acid solution.

- With respect to the electrolytic treatment, both copper and alloy electrodeposition have to be carried out in divided electrolytic cells linked in series, with sufficient recycling of the solution in the cells to allow for nearly complete copper removal and steady operation of the $\mathrm{Zn}-\mathrm{Fe}$ alloy electrodeposition.

- Estimation of reactants and energy demands in the various steps of the process, together with life cycle analysis of the whole process have to be carried out.

\section{Acknowledgments.}

This work has been partly funded by French ANRT, covering part of the PhD grant attributed to A. Maihatchi Ahamed. Most analytical facilities used in LRGP were co-funded by Region Lorraine and French Ministery of Education within the CPER SusChemProc contract. Thanks are also to P. Louis for assistance in ICP-AES analysis. 


\section{References cited}

Agrawal A., Sahu K.K., Pandey B.D., 2004. Solid waste management in non-ferrous industries in India, Resour. Conserv. Recycl. 42, 99-120. doi:10.1016/j.resconrec.2003.10.004.

Antonijevic M.M., Bogdanovic G.D., 2004. Investigation of the leaching of chalcopyritic ore in acidic solutions, Hydrometallurgy 73, 245-256. doi:10.1016/j.hydromet.2003.11.003

Asokan P., Saxena M., Asolekar S.R., 2006. Hazardous jarosite use in developing nonhazardous product for engineering application, J. Hazard. Mater. 137, 1589-1599. doi:10.1016/j.jhazmat.2006.04.054.

Brenner A., Electrodeposition of Alloys: Principles and Practice, Elsevier, 2013.

Coetzee R., Dorfling C., Bradshaw S.M., 2017. Characterization of precipitate formed during the removal of iron and precious metals from sulphate leach solutions, J. South. Afr. Inst. Min. Metall. 117, 771-778. doi:10.17159/2411-9717/2017/v117n8a7.

Davey P.T., Scott T.R., 1976. Removal of iron from leach liquors by the "Goethite" process, Hydrometallurgy. 2, 25-33. doi:10.1016/0304-386X(76)90011-6.

Demoisson F., Mullet M., Humbert B., 2008. Pyrite oxidation in acidic medium: overall reaction pathway, Surface and Interface Analysis 40, 343-348. DOI 10.1002/sia.2720.

Diaz S.L., Calderon J.A., Barcia O.E., Mattos O.R., 2008. Electrodeposition of Fe in sulfate solutions, Electrochimica Acta 53, 7426-7435. doi:10.1016/j.electacta.2008.01.015

Dutrizac J.E., 1999. The effectiveness of jarosite species for precipitating sodium jarosite, Journal of Operation Management 51, 30-32. doi:10.1007/s11837-999-0168-6.

Elgersma F., Kamst G.F., Witkamp G.J., van Rosmalen G.M., 1992. Acidic dissolution of zinc ferrite, Hydrometallurgy 29, 173-189. DOI: 10.1016/0304-386X(92)90012-O

Fan Y., Liu Y., Niu L., Jing T., Zhang W-G., Zhang T-A.. 2019. Reductive leaching of indium-bearing zinc ferrite in fulfuric acid using uulfur Dioxide as a Reductant .

Hydrometallurgy 186, 192-99. https://doi.org/10.1016/j.hydromet.2019.04.020.

Fukushima H., Akiyama T., Lee J., Yamaguchi M., Higashi K., 1983. Mechanism of the electrodeposition of zinc with iron-group metals from sulfate baths, Trans. Jpn. Inst. Met. 24, 125-131. https://doi.org/10.2320/matertrans1960.24.125.

Gómez E., Alcobe X., Vallés E., 1999. Electrodeposition of zinc+iron alloys, J. Electroanal. Chem. 475, 66-72. https://doi.org/10.1016/S0022-0728(99)00345-9.

Hallewell M., McDonald N., Thorpe R., Laframboise P., 2005. Stabilization of lead and zinc flotation circuits at Galmoy Mine, 37th Annu. Meet. Can. Miner. Process.

Jepson S., Meecham M.S., Salt F.W., 1954. The electrodeposition of iron-zinc alloys, Trans. Institute of Metal Finishing 32, 160-185. doi:10.1080/00202967.1954.11869673. 
Jha M.K., Kumar V., Singh R.J., 2001. Review of hydrometallurgical recovery of zinc from industrial wastes, Resour. Conserv. Recycl. 33, 1-22. doi:10.1016/S09213449(00)00095-1.

Lv S., Suo H., Wang H., Wang J., Xu Y., Zhao C., 2010. Effect of additives on the morphologies of silver nanostructured prepared by galvanic displacement reaction, Solid State Sciences 12, 1287-1291. doi:10.1016/j.solidstatesciences.2010.03.012.

Parkhurst D.L., Appelo C.A.J., 2013. Description of Input and examples for PHREEQC Version 3, Techniques and Methods 6-43, US Geological Survey.

Ropenack A.V., Bohmer W., 1995. Grimm H., Method of reprocessing jarosite-containing residues, US Patent US5453253A.

Sarmiento A.M., Caraballo M.A., Sanchez-Rodas D., Nieto J.M., Parviainen A., 2012.

Dissolved and particulate metals and arsenic species mobility along a stream affected by acid mine drainage in the Iberian pyrite belt (SW Spain), Appl. Geochem. 27, 19441952. doi:10.1016/j.apgeochem.2012.07.012.

Sharma P., 2016. Feasibility study of industrial jarosite waste as vital material for construction: positive and negative aspects, Malays. J. Civ. Eng. 28. doi:10.11113/mjce.v28.160.

Štrbac N., Mihajlović I., Andrić V., Živković Ž., Rosić A., 2011. Kinetic investigations of two processes for zinc recovery from zinc plant residue, Can. Metall. Q., 50(1), 28-36. doi: $10.1179 / 000844311 X 552287$

Winand, R. 2011. «Electrodeposition of Zinc and Zinc Alloys ». In Modern Electroplating, 285-307. Wiley \& Sons, Ltd. https://doi.org/10.1002/9780470602638.ch10.

Yan H., Chai L., Peng B., Li M., Peng N., Hou D., 2014. A novel method to recover zinc and iron from zinc leaching residue, Mineral Engineering 55, 103-110. doi:10.1016/j.mineng.2013.09.015.

Zaabar A., Aitout R., Amoura D., Maizia R., Makhloufi L., Saidani B., 2019. Effect of nettle plant extract on the overconsumption diminution of zinc as sacrificial metal during cementation of copper, Mineral Engineering 142, 105933.

Doi.org/10.1016/j.mineng.2019.105933.

Zhang B., Zhu L., Liu W., Han J., Jiao F., Qin W., 2019. Sulfidation and sulfur fixation of jarosite residues during reduction roasting, Metall. Mater. Trans. B. 50, 761-771. doi:10.1007/s11663-019-01517-z.

Zhang F., Wei C., Deng Z., Li C., Li X., Li M., 2016. Reductive leaching of zinc and indium from industrial zinc ferrite particulates in sulphuric acid media, Trans. Nonferrous Met. Soc. China. 26, 2495-2501. doi:10.1016/S1003-6326(16)64342-X.

Zhang Z., Leng W.H., Shao H.B., Zhang J.Q., Wang J.M., Cao C.N., Study on the behavior of Zn-Fe alloy electroplating, J. Electroanal. Chem. 516, 127-130. doi:10.1016/S0022- 
0728(01)00665-9.

\section{List of tables}

\begin{tabular}{|c|c|c|c|c|c|c|c|c|c|}
\hline & $\mathrm{Fe}$ & $\mathrm{Zn}$ & $\mathrm{Pb}$ & $\mathrm{Cu}$ & $\mathrm{Al}$ & $\mathrm{Si}$ & $\mathrm{Na}$ & $\mathrm{Ca}$ & $\mathrm{K}$ \\
\hline wt $\%$ & 22.53 & 5.83 & 4.31 & 0.24 & 1.01 & 2.44 & 1.47 & 0.80 & 5.22 \\
\hline
\end{tabular}

Table 1: Weight fractions of metals in the jarosite fraction used. Due to the presence of nonmetal elements $(\mathrm{S}, \mathrm{O})$ not given here, the sum of the weight contents is lower than $100 \%$.

\begin{tabular}{|c|c|c|c|c|c|c|c|}
\hline & $\mathrm{Fe}$ & $\mathrm{Zn}$ & $\mathrm{Pb}$ & $\mathrm{Al}$ & $\mathrm{Na}$ & $\mathrm{Ca}$ & $\mathrm{S}$ \\
\hline wt \% & 6.37 & 52.4 & 3.14 & 0.57 & 3.44 & 2.65 & 27.1 \\
\hline
\end{tabular}

Table 2: Weight fractions of metals in the blende fraction used.

\begin{tabular}{|l|c|c|c|c|c|c|}
\hline Mineral & K-jarosite & $\mathrm{ZnSO}_{4}$ & $\mathrm{PbSO}_{4}$ & $\mathrm{AlSO}_{4}$ & $\mathrm{CuSO}_{4}$ & $\mathrm{CaSO}_{4}$ \\
\hline wt \% & 67.4 & 14.4 & 6.30 & 6.38 & 0.77 & 2.7 \\
\hline
\end{tabular}

Table 3: Mineral composition of the jarosite, neglecting the presence of zinc ferrite in the industrial fraction used.

\begin{tabular}{|c|c|c|c|}
\hline Solid charge $\left(\mathrm{g} \mathrm{L}^{-1}\right)$ & $\mathrm{Fe}^{2+}\left(\mathrm{g} \mathrm{L}^{-1}\right)$ & $\mathrm{Zn}^{2+}\left(\mathrm{g} \mathrm{L}^{-1}\right)$ & $\mathrm{Cu}^{2+}\left(\mathrm{g} \mathrm{L}^{-1}\right)$ \\
\hline 100 & 17.0 & 4.1 & 0.21 \\
\hline 200 & 21.0 & 6.1 & 0.35 \\
\hline 300 & 26.6 & 9.81 & 0.50 \\
\hline
\end{tabular}

Table 4: Metal cation concentration after 7 hours of leaching at $80^{\circ} \mathrm{C}$ in a $1.5 \mathrm{M}$ sulfuric acid solution. 


\begin{tabular}{|c|c|c|c|}
\hline Factor $\mathrm{n}$ & $\mathrm{T}\left({ }^{\circ} \mathrm{C}\right)$ & $\mathrm{Zn}^{2+}\left(\mathrm{g} \mathrm{L}^{-1}\right)$ & $\mathrm{X}_{\mathrm{Fe}(\mathrm{III})}$ \\
\hline Initial solution & - & 9.81 & 0 \\
\hline 0.59 & 20 & 11.9 & $18.2 \%$ \\
\hline 0.59 & 50 & 16.8 & $49.3 \%$ \\
\hline 0.59 & 80 & 22.0 & $82.6 \%$ \\
\hline 0.42 & 50 & 14.3 & $33.3 \%$ \\
\hline
\end{tabular}

Table 5: Results of reducing blende leaching conducted for 4 hours. The initial concentration of $\mathrm{Fe}(\mathrm{III})=26.6 \mathrm{~g} \mathrm{~L}^{-1}$. $\mathrm{X}_{\mathrm{Fe}(\mathrm{III})}$ corresponds to the fraction of $\mathrm{Fe}(\mathrm{III})$ reduced by blende.

\begin{tabular}{|c|c|c|c|c|}
\hline $\begin{array}{c}\text { Current density } \\
\left(\mathrm{A} / \mathrm{m}^{2}\right)\end{array}$ & $\mathrm{wt} \% \mathrm{Zn}$ & $\mathrm{wt} \% \mathrm{Fe}$ & $\mathrm{wt} \% \mathrm{Cu}$ & $\begin{array}{c}\text { Faradaic } \\
\text { yield }(\%)\end{array}$ \\
\hline 140 & 57.0 & 26.8 & 16.2 & 21 \\
\hline 200 & 41.7 & 44.8 & 13.5 & 32 \\
\hline 340 & 43.5 & 44.3 & 12.2 & 37 \\
\hline 500 & 59.5 & 31.1 & 9.4 & 69 \\
\hline
\end{tabular}

Table 6: Results of preliminary electrodeposition tests carried out for 5 minutes with freshly $\mathrm{Cu}$-depleted leaching solution, as a function of the current density. Only $\mathrm{Fe}, \mathrm{Cu}$ and $\mathrm{Zn}$ elements could be quantified in the small amounts of deposit recovered, so the weight fractions were adjusted so that their sums equated $100 \%$. 


\section{Legends of the figures}

Figure 1: XRD spectra of the jarosite (a) and blende (b) used.

Figure 2: Schematic of the process for jarosite beneficiation.

Figure 3: Leaching tests were conducted at $80^{\circ} \mathrm{C}$ with various solid/liquid ratios, $1.5 \mathrm{M}$ $\mathrm{H}_{2} \mathrm{SO}_{4}$ : leaching efficiency of iron (a) and zinc (b) over time

Figure 4: Leaching tests conducted in $1.5 \mathrm{M} \mathrm{H}_{2} \mathrm{SO}_{4}$ at various temperatures for 7 hours: leaching efficiency of iron, zinc, and copper; solid concentrations $=100 \mathrm{~g} \mathrm{~L}^{-1}$ (a) and 300 $\mathrm{g} \mathrm{L}^{-1}$ (b)

Figure 5: Leaching efficiency for iron, zinc and copper in tests conducted with $300 \mathrm{~g} \mathrm{~L}^{-1}$ jarosite for 7 hours: effect of sulfuric acid concentration. The fractional amount of acid introduced is also given: fractions over $100 \%$ indicate excess acid was used to complete leaching.

Figure 6: Time variation of the potential of the working electrode in leaching tests of blende for reduction of $\mathrm{Fe}$ (III) to $\mathrm{Fe}$ (II) species: effect of the stoichiometric factor $\mathrm{n}=\mathrm{nb}$ moles $\mathrm{ZnS} / \mathrm{nb}$ moles $\mathrm{Fe}(\mathrm{III})$ at $50^{\circ} \mathrm{C}(\mathrm{a})$, and of the temperature for $\mathrm{n}=0.59$. Dotted lines correspond to the reversible potential of the $\mathrm{Fe}(\mathrm{II}) / \mathrm{Fe}(\mathrm{III})$ couple at $25^{\circ} \mathrm{C}$.

Figure 7: Voltammetric curves recorded at $50 \mathrm{mV} / \mathrm{s}$ for various synthetic solutions of metal cations at $\mathrm{pH} 2$.

Figure 8: Time variations of the cell current in deposition tests carried out at $-0.35 \mathrm{~V} / \mathrm{Ag}$ $\mathrm{AgCl}$ with synthetic solutions $\mathrm{S} 1\left(\mathrm{Cu}^{2+}\right), \mathrm{S} 2\left(\mathrm{Cu}^{2+}, \mathrm{Zn}^{2+}\right)$ and the recovered leachate.

Figure 9: Time variations of the anode and cathode potentials vs. $\mathrm{Ag} / \mathrm{AgCl}$ with an indication of electrode reactions occurring in italics. 
Figure 1
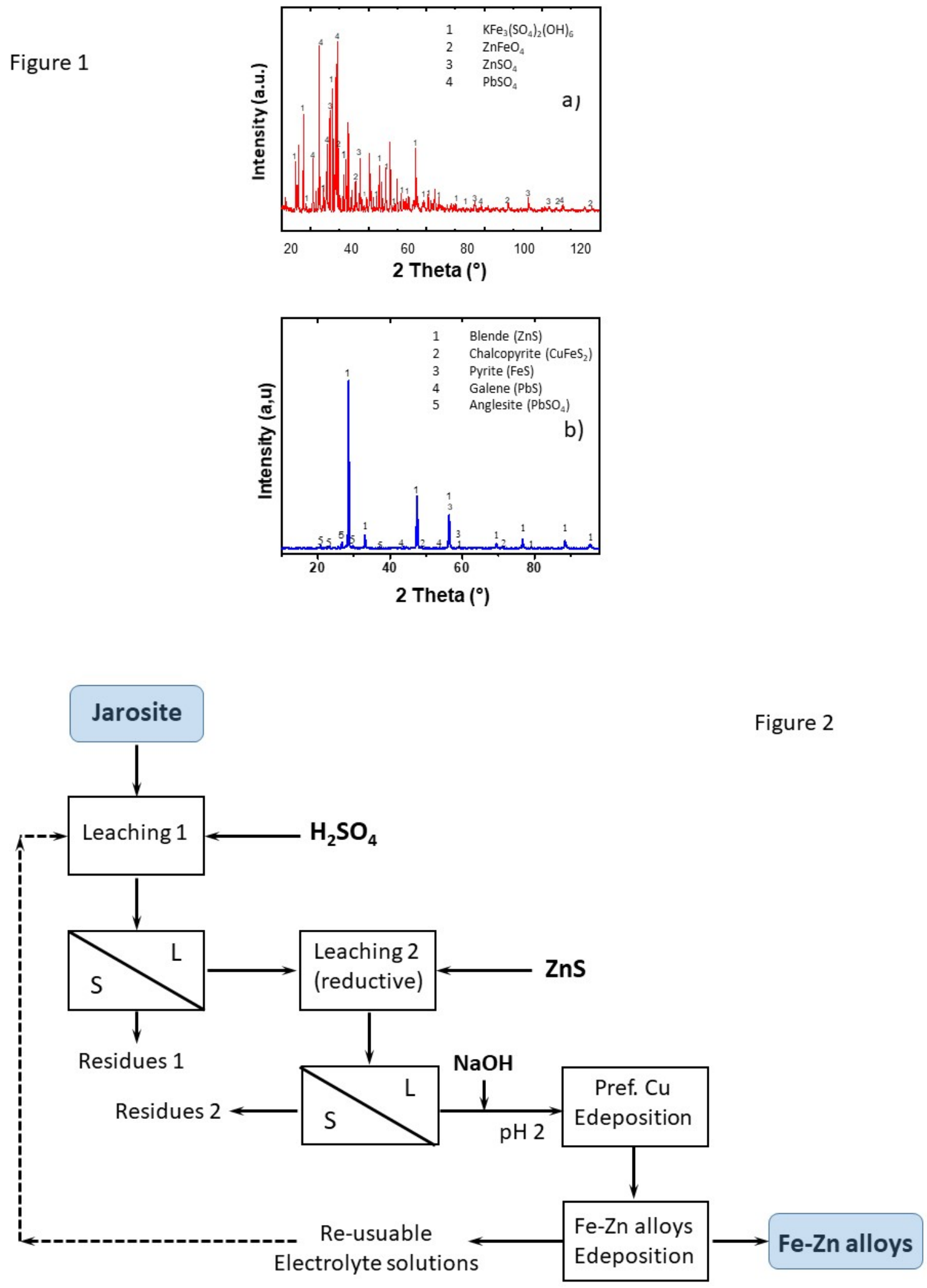
Figure 3
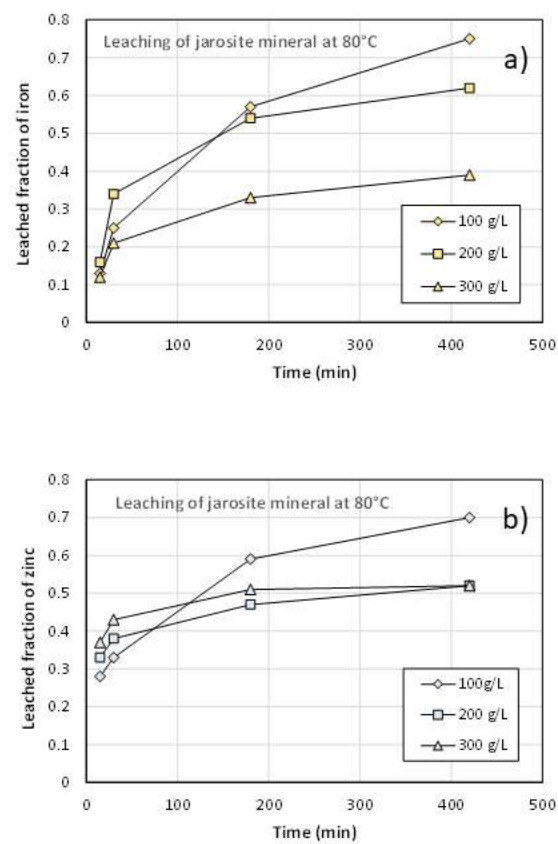

Figure 4
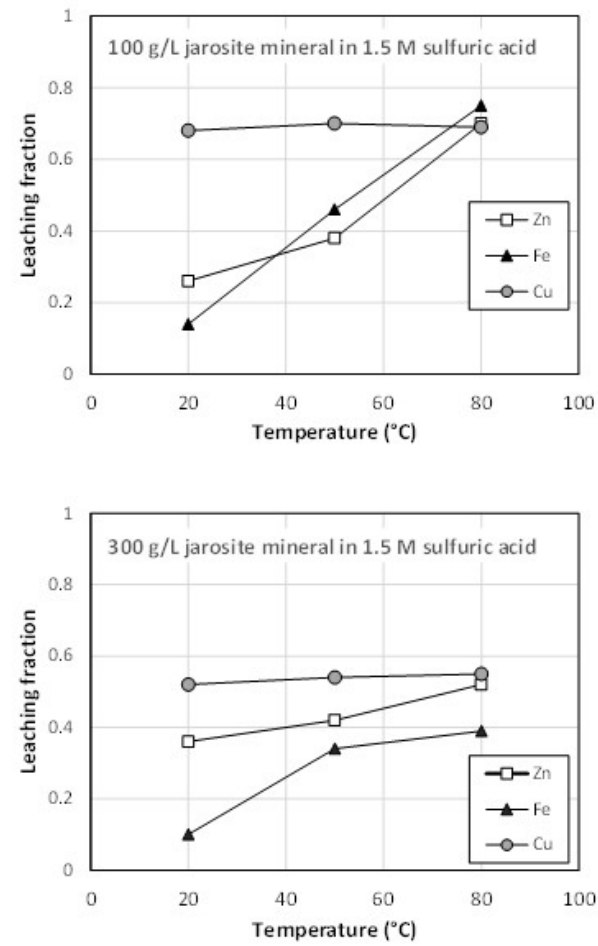

Page 22 
Figure 5
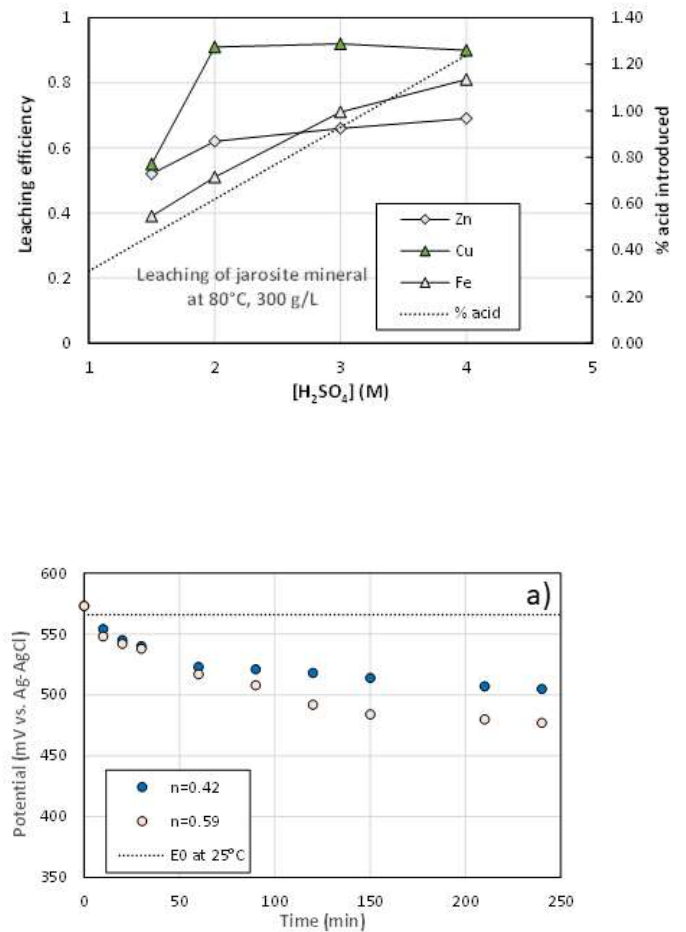

Figure 6

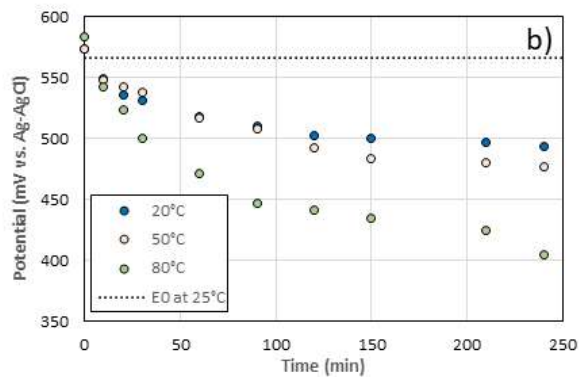


Figure 7

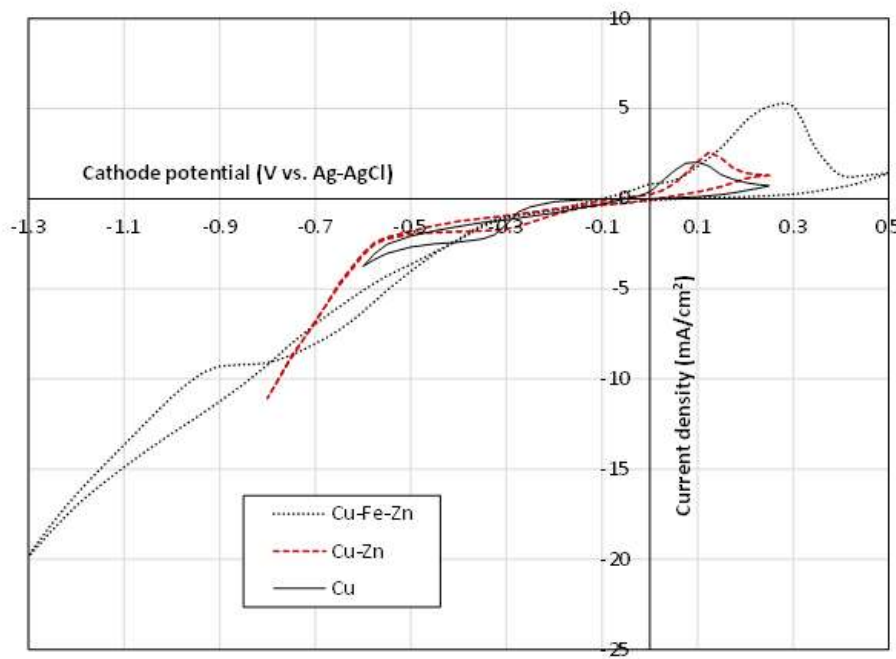

Figure 8

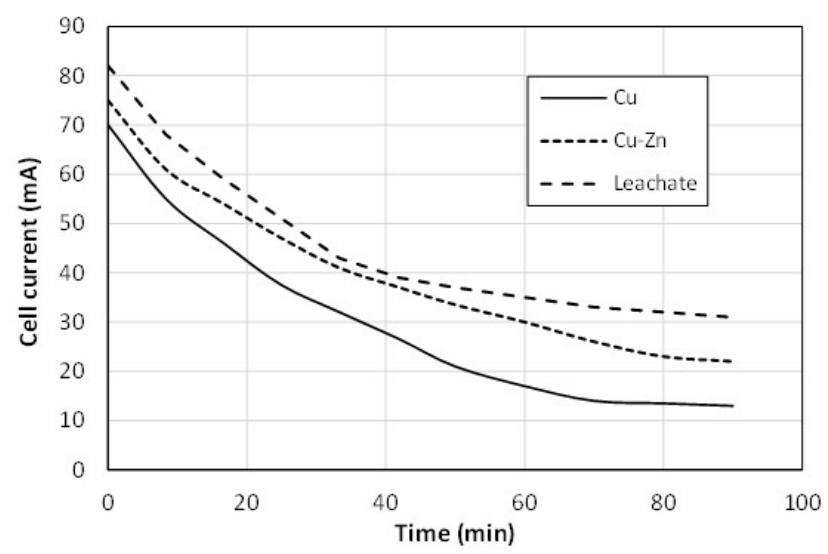

Figure 9

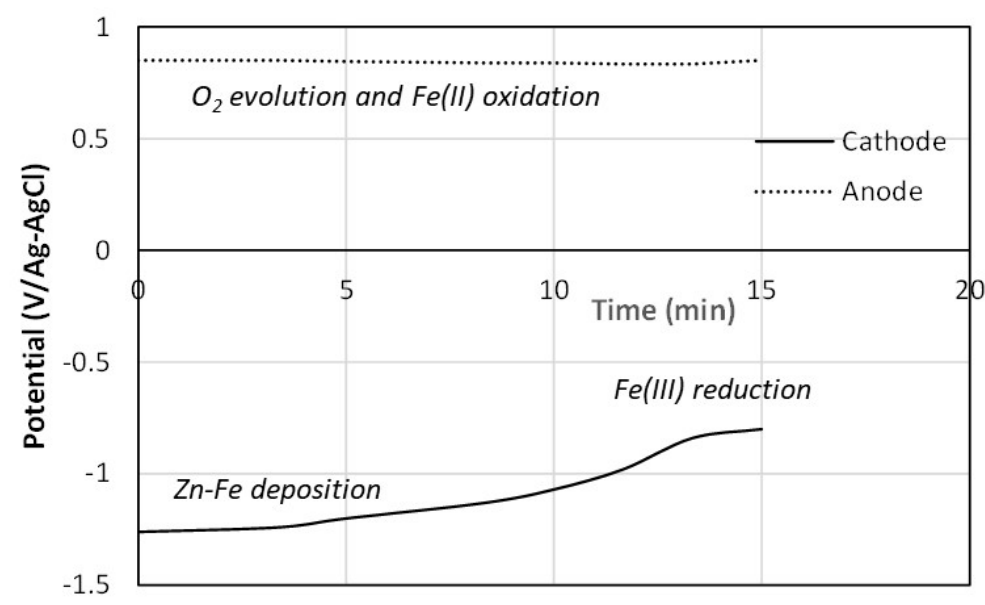

